\title{
POST-VACCINAL IMMUNITY TO DIPHTHERIA, MEASLES, TETANUS AND PERTUSSIS IN CHILDREN EXPOSED TO ENVIRONMENTAL CHEMICAL FACTORS $^{1}$
}

\author{
O. Ustinova, V. Makarova, O. Dolgikh, A. Aminova
}

Federal Budget Scientific Institution "Federal Scientific Center for Medical and Preventive Health Risk Management Technologies"

Russia, 614045, Perm, 82, Monastyrskaya str.

\begin{abstract}
An assessment of post-vaccination immunity against diphtheria, measles, tetanus and pertussis in children with increased levels of chemical toxicants, caused by environmental exposure, determined that the levels of postvaccination antibodies in this group of children were significantly lower than those in children living in environmentally favorable areas and that disorders in the development of post-vaccination immunity were observed 1.5 to 2.4 times more often. We identified a true relationship between a decrease in the levels of specific postvaccination antibodies and an increase in the levels of lead, chromium, manganese and o-cresol in the blood.

Keywords: children, post-vaccination immunity, diphtheria, pertussis, measles, tetanus, environmental exposure, chemical factors.
\end{abstract}

Introduction. Planed preventative vaccination has reduced the incidence of a number of infections in many countries. Preventative vaccination reportedly prevents approximately 3 million deaths from pertussis, measles, tetanus, diphtheria annually [3, 13]. At the same time, technogenic pollution decreases the immunological effectiveness of the vaccination in children and may result in epidemic ill-being [1, 4, 5, 6, 7, 8, 17].

A post-hoc analysis of the diphtheria epidemic (1996-1996) shows that a lot of the patients have been vaccinated (74-81\%) which indicates an insignificant level of vaccineinduced immunity in certain population groups $[1,12]$. In adult diphtheria patients, the number of vaccinated patients constituted $65-70 \%$, in children - more than $80 \%$ [11]. A similar pattern is noted regarding pertussis incidence [9]. New measles cases are registered in the immunized people including re-vaccinated patients [13]. Among all the patients, $20.5 \%$ received live measles vaccine including $13.2 \%$ that received 2 does of the vaccine. There have been reported cases of tetanus among the immunized patients [13].

Many researchers report that technogenic pollution is one of the leading risk factors that lead to the development of a low level of vaccine-induced anti-bodies in 35-51.9\% of children $[8,14,15]$. In the areas of unfavorable sanitary and hygienic conditions, the number of children with a maximal level of anti-diphtheria anti-bodies is $7-8$ times lower as compared to the similar indicator in children residing in the areas with relatively favorable conditions $[9,14,16]$. It has been reported that among children aged 10-14 residing in the areas of technogenic pollution, 20$25 \%$ do not have a protective level of anti-bodies to diphtheria, $28-37 \%$ - to measles, and $90 \%$ - to pertussis $[10,18,20]$.

According to the research findings, environmental pollution caused by technogenic chemical toxicants (lead, manganese, chrome, phenol, aromatic hydrocarbons) at the level of 1.01-5.0 maximum permissible contamination MPC average daily leads to a higher level of these toxicants in the blood that is $1.5-5.3$ times higher as compared to the reference level [4, 5,

\footnotetext{
${ }^{1}$ Translated by Ksenya Zemnlyanova
} 
$6,7]$. Higher concentration of these toxic compounds in the biological medias determined by various routes of entry into the body (water, aerobic, food, etc.) results in the condition of secondary immune deficiency $[4,6,11]$. Children with contamination of the biological medias caused by the above toxicants at the levels that exceed the reference/background values have been reported to have a lower level, as compared to the physiological standard, of the immunocompetent cells that actively participate in the development of vaccine-induced immunity: absolute and relative mature T-lymphocyte count (and the subpopulations) count (CD4+, CD8+), killer cell count (CD16+CD56+), antibody-producing cell count (CD19+) and $\mathrm{T}_{\mathrm{x}} 1$ mediator depression against simultaneous increase in $\mathrm{CD} 25^{+}, \mathrm{CD} 95^{+}$, general and specific hypersensitivity (IgE) as well as $\mathrm{T}_{\mathrm{x}} 2$ type cytokine production (IL-4, IL-6) $[2,14,16]$. Decrease in immunologic reactivity is accompanied by nonspecific resistance depression (reduction in the absolute count and functional activity of phagocytes against IgG and IgA deficit) that prevents the development of a full-scale vaccine-induced immunity [2, 8, 17].

Current application of local diagnostic systems for a qualitative and quantitative assessment of the vaccine-induced immunity based on an agglutination reaction or passive hemagglutination does not provide a full picture about the directional effect of specific antibodies to various causative agents and about the actual protective activity of those antibodies [19]. The IFA method meets the above requirements at the fullest; its main advantages include high sensitivity and specificity, a possibility to study a large amount of samples at the same time and determine specific antibodies of different classes $\mathrm{JgA}, \mathrm{JgM}, \mathrm{JgG}, \mathrm{JgE}$, objective evaluation of the results, easy determination and a possibility of internal control.

The purpose of this research is to study the correlation between the vaccine-induced dysimmunity to diphtheria, measles, tetanus, and pertussis in children with a higher level of chemical toxicants in the blood determined by external environmental impact.

Materials and methods. The object of the research is 276 children aged 4-6 which in accordance with the National Immunization Schedule were vaccinated against diphtheria, pertussis, and tetanus with AKDS vaccine (basic immunization at the age of 3,4,5 and 6 months, and first re-immunization at 18 months), and against measles - with KJV vaccine (immunization at the age of 12 months, re-imminization - at 6 years old), and did not have vaccine-induced reactions. 219 children (study group) resided in a large industrial center with multi-industry enterprises, and 57 children (control group) resided in an area with relatively favorable sanitary and hygienic conditions. The groups were homogenous in terms of gender composition and socioeconomic characteristics. Children with pathologies including immune disorders were not included in the study.

A hygienic assessment of the impact on the atmospheric air in the areas of the children's residents was conducted on the basis of the analysis of the quantitative composition of the industrial emissions under 2-TP-air form. To assess the air quality, we used the official monitoring data provided by Russia's Rospotrebnadzor as well as the results of own field observations of the air quality in the areas of exposure.

Assessment of the risk of immune disorders in children was conducted in accordance with a standardized procedure based on the Guidelines for public health risk assessment under chemical environmental pollution (P 2.1.10.1920-04). 
A chemical analysis of the metal content (manganese, lead, chrome) in biosubstrate (blood) and the atmospheric air was conducted with the help of atomic absorption spectrophotometry using the PERKIN-ELMER-3110 spectrometer (USA) (State Registry Number 14427-95) with atomization in the flame and mass-spectrometer with ICP-MS inductively-coupled plasma by Agilent 7500cx (USA) (State Registry Number 24863-08). The analysis of phenol and O-cresol in biosubstrates (blood) and the atmospheric air was conducted with the help of capillary gas chromatography method and paraphrase analysis in accordance with the methodological guidelines (MUK 4.1.763-4.1.779-99; MUK 4.1.2102-4.1.2116-06) using a gas chromatograph (7890A model, State Registry Number 15118-07) (USA) and Chromatec Crystal 5000 gas chromatograph (№ FSR 2009/04091, TU 9443-004-12908609-99). Assessment of the postvaccinal antibody count was conducted with the use of enzyme multiplied immunoassay method on a semi-automatic immunoanalyzer ELx808 with the use of:

a) test system Anti-Diphtheria Toxoid ELISA aimed for quantitative determination in vitro IgG class antibodies (as well as IgM and IgA class) to diphtherial anatoxin (Diphtheria toxoid) in blood serum dimensioned in International Units with the use of international reference serum NIBSC 91|534 (National Institute for Biological Standards Control, Hertfordshire, England);

b) test systems RIDASCREEN Bordetella IgG ELISA aimed for quantitative determination in vitro of IgG class antibodies to pertussis toxoid (Bordetella toxoid) in blood serum;

c) test systems Anti-Measles Viruses ELISA (IgG) aimed for quantitative in vitro determination of IgG class antibodies (as well as IgM and IgA class) to measles virus in blood serum;

d) test systems Anti-Tetanus Toxoid ELISA aimed for quantitative determination in vitro of IgG class antibodies to tetanus toxoid in blood serum measured in International Units with the use of international reference serum (I International Standard of antibodies to tetanus, Human NIBSC Code TE-3).

Assessment of the vaccine-induced immunity to diphtheria, pertussis, and tetanus was conducted three, four, and five years after the first AKDS re-immunization; to measles causative agent - three and four years after the vaccination, and one year - after KJV re-immunization on the basis of the analysis of the circulatory specific vaccine-induced antibodies count.

Assessment of intergroup differences of the analyzed indicators was conducted with the use of standard parametric statistics methods. On the basis of logistic models, we evaluated the dependency between the development of vaccine-induced dysimmunity (postvaccinal antibodies below the protective level) and higher (as compared to the reference/background level) level of chemical toxicants in the blood associated with external environmental impact. When modelling by odds ratio, we assesses the inactive levels of manganese, lead, chrome, and O-cresol on the development of vaccine-induce immunity to diphtheria, pertussis, tetanus, and measles.

Results. It was reported that in the areas of residence of the children from the observation group (a big industrial center with multi-industrial enterprises), over 900 tons of pollutants (including chrome, manganese, lead, phenol, and cresol compounds) were emitted in the air 
annually from stationary sources; 1-3 hazard class chemicals constituted over $77 \%$ of those pollutants (759.6 t/year).

Field observations of the atmospheric air in the exposure areas helped identify chrome, lead, and manganese in the collected samples - in the concentration up to 1.5 MPC average daily, cresol and phenol - up to 2.3-4.0 MPC average daily.

In the area of the residence of the children from the control group (urban-type settlement), the air quality met the hygienic standards in terms of monitoring and field observations.

In the course of the studies conducted in the areas of the residence of children from the observation group we determined an impermissible risk level of dysimmunities (HI $>1,0)$ with inhalation intake of the studied compounds (chrome, manganese, lead). Epidemiological research results revealed a cause-and-effect relationship between the studied chemical risk factors and development of dysimmunities (Chance Ratio $=2,56$; Confidence Interval $=1,05-6,26$ ).

When assessing the risk of development of dysimmunities associated with the environmental chemical impact in the areas of residence of children from the control group, we determined a permissible risk level of dysimmunities $(\mathrm{HI}<1,0)$.

Chemico-analytical analysis of the blood of children from the observation group showed that the level of manganese $\left(0,021 \pm 0,003 \mathrm{mg} / \mathrm{dm}^{3}\right)$, lead $\left(0,131 \pm 0,013 \mathrm{mg} / \mathrm{dm}^{3}\right)$, chrome $\left(0,0191 \pm 0,0035 \mathrm{mg} / \mathrm{dm}^{3}\right)$, phenol $\left(0,0494 \pm 0,0071 \mathrm{mg} / \mathrm{dm}^{3}\right)$ and o-cresol $(0,0143 \pm 0,0046$ $\left.\mathrm{mg} / \mathrm{dm}^{3}\right)$ accurately $(\mathrm{p}=0,01-0,0001)$ exceeds the reference / background levels by 1,4-4,0 times. Additionally, concentrations of these chemical elements was 1,2-4,9 times higher as compared to the similar indicators in the control group (manganese $-0,013 \pm 0,0024 \mathrm{mg} / \mathrm{dm}^{3}$, lead

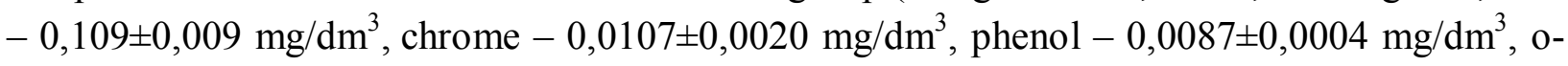
cresol $\left.-0,0033 \pm 0,0012 \mathrm{mg} / \mathrm{dm}^{3} ; \mathrm{p}=0,03-0,0001\right)$ (Table 1).

Table 1

Chemical levels in the blood of children residing in the areas of favorable sanitary and hygienic conditions, $\mathrm{mg} / \mathrm{dm}^{3}$

\begin{tabular}{|l|c|c|c|}
\hline \multicolumn{1}{|c|}{ Chemical } & Observation group & Control group & $\mathrm{p}$ \\
\hline Manganese & $0,021 \pm 0,003$ & $0,013 \pm 0,0024$ & $\mathbf{0 , 0 0 0 1}$ \\
\hline Lead & $0,131 \pm 0,013$ & $0,109 \pm 0,009$ & $\mathbf{0 , 0 0 6}$ \\
\hline Chrome & $0,0191 \pm 0,0035$ & $0,0107 \pm 0,0020$ & $\mathbf{0 , 0 3}$ \\
\hline Phenol & $0,0494 \pm 0,0071$ & $0,0087 \pm 0,0004$ & $\mathbf{0 , 0 0 0 1}$ \\
\hline O-cresol & $0,0143 \pm 0,0046$ & $0,0033 \pm 0,0012$ & $\mathbf{0 , 0 0 0 1}$ \\
\hline
\end{tabular}

$\mathrm{p}$ - accuracy of differences between the observation group and the control group

Analysis of the average group antibodies count (diphtheria, pertussis, tetanus, and measles) showed that their level in both groups under analysis in the period of study after the vaccination / first re-vaccination equaled the protective level. In the observation group, the level of vaccine-induced antibodies to diphtheria toxin totaled: $\mathrm{min}-0,089 \mathrm{mU} / \mathrm{ml}$ (protective level 0,1-2,0 $\mathrm{mU} / \mathrm{ml}, \mathrm{p}=0,82), \max -0,365 \mathrm{mU} / \mathrm{ml}(\mathrm{p} \leq 0,001)$, to tetanus antitoxin $-\min -0,11$ $\mathrm{mU} / \mathrm{ml}$ (protective level $-0,01-5,0 \mathrm{mU} / \mathrm{ml}, \mathrm{p} \leq 0,001), \max -0,73 \mathrm{MU} / \mathrm{ml}(\mathrm{p} \leq 0,001)$, к 
возбудителю коклюша - $\min$ - 19,13 Un/ml (protective level - 14,0-18,0 Un/ml, p = 0,02), $\max -39,19(p \leq 0,001)$, to measles agent $-\min -933,78 \mathrm{mU} / \mathrm{ml}$ (protective level $-200,0-275,0$ $\mathrm{mU} / \mathrm{ml}, \mathrm{p} \leq 0,001), \max -1126,43 \mathrm{mU} / \mathrm{ml}(\mathrm{p} \leq 0,001)$ (Table 2). At the same time, in children from the observation group 3 years after the first AKDS re-vaccination, the level of antibodies to diphtheria toxin $(0,089 \pm 0,096 \mathrm{mU} / \mathrm{ml})$ and tetanus antitoxi $(0,11 \pm 0,09 \mathrm{mU} / \mathrm{ml})$ was 4,8-10,4 times lower as compared to the indicators in the control group $(0,429 \pm 0,131 \mathrm{mU} / \mathrm{ml}$ and $1,14 \pm 0,66 \mathrm{mU} / \mathrm{ml}$ respectfully; $\mathrm{p}=0,002-0,0001)$; 4 years after $-1,4$ times lower to pertussis agent $(30,07 \pm 7,69 \mathrm{Un} / \mathrm{ml}$ against $43,31 \pm 2,0 \mathrm{Un} / \mathrm{ml}, \mathrm{p}=0,001)$, and in all the periods of analysis, the level of antibodies to measles agent after $\mathrm{KJV}$ vaccination/re-vaccination was $(1126,43 \pm 166,12 \mathrm{MU} / \mathrm{ml}, 933,78 \pm 132,25 \mathrm{MU} / \mathrm{ml}, 1043,39 \pm 169,8 \mathrm{MU} / \mathrm{ml})$ and 1,3-1,6 times lower as the control group $(1457,87 \pm 142,11 \mathrm{MU} / \mathrm{ml}, 1493,13 \pm 180,94 \mathrm{MU} / \mathrm{ml}, 1314,31 \pm 170,44$ $\mathrm{MU} / \mathrm{ml} ; \mathrm{p}=0,025-0,0001$ ) (Table 2).

For a more profound assessment of the immunological effectiveness of the AKDS and KJV vaccination in the groups under study, we analyzed the frequency of occurrence of vaccineinduced dysimmunity (Table 3). The study results showed that in 50-67\% of children in the observation group and $21-46 \%$ of children in the control group, the level of vaccine-induced antibodies did not provide protective level of immunity to diphtheria and pertussis, and the occurrence of low titers of vaccine-induced antibodies in children from the observation group was $1,8-2,0$ times higher as compared to the control group $(p=0,03-0,0001)$, at the same time, vaccine-induced measles dysimmunity in both groups occurred only in several cases (3-6\%). In all the children under review, the level of vaccine-induced antibodies to tetanus antitoxic in the period under analysis equaled the protective level. 
Vaccine-induced antibody concentration in children with different levels of technogenic chemical toxins in the blood

\begin{tabular}{|c|c|c|c|c|c|c|c|c|}
\hline \multirow{3}{*}{ Nosology } & \multicolumn{3}{|c|}{$\begin{array}{l}\text { Period since the last vaccination/re- } \\
\text { vaccination (years) }\end{array}$} & \multicolumn{4}{|c|}{ Antibody level } & \multirow{3}{*}{$\begin{array}{c}\text { Protective } \\
\text { level of } \\
\text { antibodies }\end{array}$} \\
\hline & \multirow[b]{2}{*}{$\begin{array}{l}\text { Observation } \\
\text { group }\end{array}$} & \multirow[b]{2}{*}{$\begin{array}{l}\text { Control } \\
\text { group }\end{array}$} & \multirow{2}{*}{$\begin{array}{c}\text { Accuracy } \\
\text { of } \\
\text { differences }\end{array}$} & \multirow[b]{2}{*}{$\begin{array}{l}\text { Observation } \\
\text { group }\end{array}$} & \multirow[b]{2}{*}{ Control group } & \multicolumn{2}{|c|}{$\begin{array}{l}\text { Accuracy of differences between } \\
\text { the observation group }\end{array}$} & \\
\hline & & & & & & $\begin{array}{c}\text { and } \\
\text { control } \\
\text { group }\end{array}$ & $\begin{array}{l}\text { and protective level } \\
\text { of antibodies }\end{array}$ & \\
\hline \multirow{3}{*}{$\begin{array}{l}\text { Diphtheria } \\
(\mathrm{mU} / \mathrm{ml})\end{array}$} & $3,22 \pm 1,18$ & $3,40 \pm 0,68$ & 0,79 & $0,089 \pm 0,016$ & $0,429 \pm 0,131$ & 0,0001 & 0,82 & \multirow{3}{*}{$0,1-2,0$} \\
\hline & $4,50 \pm 0,26$ & $4,24 \pm 0,22$ & 0,13 & $0,365 \pm 0,084$ & $0,264 \pm 0,154$ & 0,25 & $<0,001$ & \\
\hline & $5,16 \pm 0,38$ & $5,10 \pm 0,20$ & 0,83 & $0,289 \pm 0,089$ & $0,261 \pm 0,120$ & 0,71 & $<0,001$ & \\
\hline \multirow{3}{*}{$\begin{array}{l}\text { Tetanus } \\
(\mathrm{mU} / \mathrm{ml})\end{array}$} & $3,22 \pm 1,18$ & $3,40 \pm 0,68$ & 0,79 & $0,11 \pm 0,09$ & $1,14 \pm 0,66$ & 0,002 & $<0,001$ & \multirow{3}{*}{$0,01-5,0$} \\
\hline & $4,50 \pm 0,26$ & $4,24 \pm 0,22$ & 0,13 & $0,73 \pm 0,19$ & $0,68 \pm 0,44$ & 0,83 & $<0,001$ & \\
\hline & $5,16 \pm 0,38$ & $5,10 \pm 0,20$ & 0,83 & $0,51 \pm 0,17$ & $0,50 \pm 0,22$ & 0,94 & $<0,001$ & \\
\hline \multirow{3}{*}{$\begin{array}{l}\text { Pertussis } \\
(\mathrm{mU} / \mathrm{ml})\end{array}$} & $3,22 \pm 1,18$ & $3,40 \pm 0,68$ & 0,79 & $19,13 \pm 4,19$ & $21,83 \pm 10,19$ & 0,62 & 0,02 & \multirow{3}{*}{$14-18$} \\
\hline & $4,50 \pm 0,26$ & $4,24 \pm 0,22$ & 0,13 & $30,07 \pm 7,69$ & $43,31 \pm 2,0$ & 0,001 & $<0,001$ & \\
\hline & $5,16 \pm 0,38$ & $5,10 \pm 0,20$ & 0,83 & $39,19 \pm 10,07$ & $35,89 \pm 18,84$ & 0,76 & $<0,001$ & \\
\hline \multirow{3}{*}{$\begin{array}{l}\text { Measles } \\
(\mathrm{mU} / \mathrm{ml})\end{array}$} & $0,91 \pm 0,15$ & $1,11 \pm 0,17$ & 0,08 & $1126,43 \pm 166,12$ & $1457,87 \pm 142,11$ & 0,003 & $<0,001$ & \multirow{3}{*}{$200-275$} \\
\hline & $3,88 \pm 0,54$ & $3,98 \pm 0,76$ & 0,83 & $933,78 \pm 132,25$ & $1493,13 \pm 180,94$ & 0,0001 & $<0,001$ & \\
\hline & $4,84 \pm 0,17$ & $4,94 \pm 0,12$ & 0,34 & $1043,39 \pm 169,8$ & $1314,31 \pm 170,44$ & 0,025 & $<0,001$ & \\
\hline
\end{tabular}


Frequency of disorders of the development of a protective level of vaccine-induced immunity in children

Table 3 with different level of technogenic chemical toxicants in the blood (\%)

\begin{tabular}{|c|c|c|c|c|c|c|c|c|c|c|c|c|}
\hline \multirow[b]{2}{*}{ Nosology } & \multicolumn{3}{|c|}{$\begin{array}{l}\text { Period since the last vaccination/re- } \\
\text { vaccination (years) }\end{array}$} & \multicolumn{3}{|c|}{ Observation Group } & \multicolumn{3}{|c|}{ Control Group } & \multicolumn{3}{|c|}{ Accuracy of differences } \\
\hline & $\begin{array}{l}\text { Observation } \\
\text { Group }\end{array}$ & $\begin{array}{l}\text { Control } \\
\text { Group }\end{array}$ & $\begin{array}{c}\text { Accuracy } \\
\text { of } \\
\text { differences }\end{array}$ & $\begin{array}{c}\text { Below } \\
\text { protective } \\
\text { level }\end{array}$ & $\begin{array}{c}\text { Equal to } \\
\text { protective } \\
\text { level }\end{array}$ & $\begin{array}{c}\text { Above } \\
\text { protective } \\
\text { level }\end{array}$ & $\begin{array}{c}\text { Below } \\
\text { protective } \\
\text { level }\end{array}$ & $\begin{array}{c}\text { Equal to } \\
\text { protective } \\
\text { level }\end{array}$ & $\begin{array}{c}\text { Above } \\
\text { protective } \\
\text { level }\end{array}$ & $\mathrm{p} 1$ & $\mathrm{p} 2$ & p3 \\
\hline \multirow{3}{*}{ Diphtheria } & $3,22 \pm 1,18$ & $3,40 \pm 0,68$ & 0,79 & 52 & 46 & 2 & 29 & 71 & 0 & $\mathbf{0 , 0 0 3}$ & 0,001 & - \\
\hline & $4,50 \pm 0,26$ & $4,24 \pm 0,22$ & 0,13 & 52 & 48 & 0 & 46 & 54 & 0 & 0,44 & 0,44 & - \\
\hline & $5,16 \pm 0,38$ & $5,10 \pm 0,20$ & 0,83 & 67 & 33 & 0 & 33 & 67 & 0 & $\mathbf{0 , 0 0 1}$ & 0,001 & - \\
\hline \multirow{3}{*}{ Tetanus } & $3,22 \pm 1,18$ & $3,40 \pm 0,68$ & 0,79 & 0 & 100 & 0 & 0 & 100 & 0 & - & 1,0 & - \\
\hline & $4,50 \pm 0,26$ & $4,24 \pm 0,22$ & 0,13 & 0 & 99 & 1 & 0 & 100 & 0 & - & 0,99 & - \\
\hline & $5,16 \pm 0,38$ & $5,10 \pm 0,20$ & 0,83 & 0 & 100 & 0 & 0 & 100 & 0 & - & 1,0 & - \\
\hline \multirow{3}{*}{ Pertussis } & $3,22 \pm 1,18$ & $3,40 \pm 0,68$ & 0,79 & 50 & 8 & 42 & 21 & 7 & 71 & 0,0001 & 0,9 & 0,0001 \\
\hline & $4,50 \pm 0,26$ & $4,24 \pm 0,22$ & 0,13 & 53 & 3 & 43 & 30 & 26 & 44 & $\mathbf{0 , 0 0 3}$ & $\mathbf{0 , 0 0 0 1}$ & $\mathbf{0 , 0 2}$ \\
\hline & $5,16 \pm 0,38$ & $5,10 \pm 0,20$ & 0,83 & 50 & 32 & 18 & 27 & 57 & 16 & $\mathbf{0 , 0 3}$ & 0,001 & 0,73 \\
\hline \multirow{3}{*}{ Measles } & $0,91 \pm 0,15$ & $1,11 \pm 0,17$ & 0,08 & 3 & 3 & 94 & 0 & 20 & 80 & 0 & 0,0001 & $\mathbf{0 , 0 0 1}$ \\
\hline & $3,88 \pm 0,54$ & $3,98 \pm 0,76$ & 0,83 & 0 & 1 & 99 & 6 & 0 & 94 & - & - & 0,87 \\
\hline & $4,84 \pm 0,17$ & $4,94 \pm 0,12$ & 0,34 & 0 & 0 & 100 & 0 & 0 & 100 & - & - & - \\
\hline
\end{tabular}

$\mathrm{p}^{1}$ - accuracy of differences in the frequency of development of vaccine-induced immunity below the protective level in children from the observation group and the control group

$\mathrm{p}^{2}$ - accuracy of differences in the frequency of occurrence of a protective level of vaccine-induced antibodies in children from the observation group and the control group

$\mathrm{p}^{3}$ - accuracy of differences in the frequency of development of vaccine-induced immunity above the protective level in children from the observation group and the control group 
In the observation groups, in the post-vaccinal period of analysis, protective level of anti-diphtheria antibodies was registered only in 33-48 \% of immunized children which is accurately 1,5-2,0 times lower as compared to the control group $(67-71 \% p=0,003-0,0001)$. The level of vaccine-induce anti-pertussis antibodies at the protective level and higher in the observation group was registered only in 46-50\% of children; at the same time, this indicator in the control group was 1,5-1,6 times higher $(70-78 \%, \mathrm{p}=0,003-0,0001)$. Overall, in the observation group, the number of children with a low level of vaccine-induced anti-diphtheria antibodies was $1,8-2,0$ times $(\mathrm{p}=0,001-0,003)$ higher as compared to the control group; the number of children with a level of anti-pertussis antibodies lower as compared to the protective level was $1,5-2,4$ times higher $(\mathrm{p}=0,03-0,0001)$ (Table 3).Additionally, in the post-vaccinal period under analysis (from 3 to 5 years), the number of children in the observation group with a lower level of anti-diphtheria antibodies as compared to the protective level increased by 28,9 $\%$; in the control group, this indicater constituted $13,8 \%(\mathrm{p}=0,03)$.

The study of the indicators of the system immunity showed that the children residing in the areas of human-caused environmental pollution had a significantly lower as compared to the control group absolute level of lymphocytes CD19+ и CD16 $+56+(p=0,01-0,001)$ and immune serum globulin A $(\mathrm{p}=0,02)$ (Table 4$)$.

Table 4

Indicators of system immunity in children with different levels of technogenic chemical toxicants in the blood

\begin{tabular}{|c|c|c|c|c|}
\hline Indicator & $\begin{array}{l}\text { Physiological } \\
\text { level }\end{array}$ & $\begin{array}{l}\text { Observation } \\
\text { group }\end{array}$ & $\begin{array}{l}\text { Control } \\
\text { group }\end{array}$ & $p$ \\
\hline Phagocytosis percentage ( \%) & $35-60$ & $56,0 \pm 2,5$ & $56,5 \pm 4,5$ & 0,92 \\
\hline Phagocytic number (standard unit) & $0,8-1,2$ & $1,05 \pm 0,08$ & $1,0 \pm 0,09$ & 0,40 \\
\hline Phagocytic index (standard unit & $1,5-2,0$ & $1,85 \pm 0,08$ & $1,70 \pm 0,12$ & 0,06 \\
\hline Absolute phagocytosis $\left(10^{9} / \mathrm{dm}^{3}\right)$ & $0,964-2,988$ & $2,541 \pm 0,247$ & $2,170 \pm 0,323$ & 0,07 \\
\hline CD3+-lymphocytes rel. ( \%) & $55-84$ & $67,5 \pm 2,0$ & $66,5 \pm 6,5$ & 0,89 \\
\hline CD3+- lymphocytes abs. $\left(10^{9} / \mathrm{dm}^{3}\right)$ & $0,690-2,540$ & $2,037 \pm 0,213$ & $2,160 \pm 0,276$ & 0,48 \\
\hline CD3+CD4+- lymphocytes rel. ( \%) & $31-60$ & $34,5 \pm 2,5$ & $38,0 \pm 4,0$ & 0,64 \\
\hline CD3+CD4+- lymphocytes abs. $\left(10^{9} / \mathrm{dm}^{3}\right)$ & $0,410-1,590$ & $1,047 \pm 0,132$ & $1,233 \pm 0,166$ & 0,08 \\
\hline CD3+CD8+- lymphocytes rel. ( \%) & $13-41$ & $25,5 \pm 2,0$ & $23,0 \pm 3,0$ & 0,71 \\
\hline CD3+CD8+- lymphocytes abs. $\left(10^{9} / \mathrm{dm}^{3}\right)$ & $0,190-1,140$ & $0,773 \pm 0,089$ & $0,757 \pm 0,112$ & 0,82 \\
\hline CD19+- lymphocytes rel. ( \%) & $6-25$ & $13,5 \pm 1,5$ & $17,0 \pm 2,5$ & 0,52 \\
\hline CD19+- lymphocytes abs. $\left(10^{9} / \mathrm{dm}^{3}\right)$ & $0,090-0,660$ & $0,417 \pm 0,065$ & $0,545 \pm 0,079$ & $\mathbf{0 , 0 1}$ \\
\hline CD16+56+- lymphocytes rel. ( \%) & $5-27$ & $15,5 \pm 2,5$ & $8,0 \pm 1,5$ & 0,16 \\
\hline CD16+56+lymphocytes abs. $\left(10^{9} / \mathrm{dm}^{3}\right)$ & $0,090-0,590$ & $0,463 \pm 0,084$ & $0,253 \pm 0,05$ & $\mathbf{0 , 0 0 1}$ \\
\hline CD3+CD25+- lymphocytes rel. ( \%) & 5,5 & $4,5 \pm 0,5$ & $4,5 \pm 0,5$ & 1,0 \\
\hline $\begin{array}{l}\text { CD3+CD25+- lymphocytes abs. } \\
\left(10^{9} / \mathrm{dm}^{3}\right)\end{array}$ & 0,155 & $0,136 \pm 0,023$ & $0,154 \pm 0,021$ & 0,26 \\
\hline $\operatorname{IgA}\left(\mathrm{g} / \mathrm{dm}^{3}\right)$ & $2,0-2,8$ & $1,14 \pm 0,07$ & $1,29 \pm 0,11$ & $\mathbf{0 , 0 2}$ \\
\hline $\operatorname{IgM}\left(\mathrm{g} / \mathrm{dm}^{3}\right)$ & $1,0-1,6$ & $1,09 \pm 0,04$ & $1,17 \pm 0,09$ & 0,1 \\
\hline $\operatorname{IgG}\left(\mathrm{g} / \mathrm{dm}^{3}\right)$ & $12,0-16,0$ & $10,01 \pm 0,33$ & $10,25 \pm 0,73$ & 0,35 \\
\hline
\end{tabular}

$\mathrm{p}$ - accuracy of the differences between the indicators of system immunity in children from the observation group and the control group 
The ratio analysis of the chances of changes in the level of vaccine-induced specific immunity under different toxicant load showed the presence of an accurate relationship between a decrease in $\operatorname{IgG}$ level to diphtheria anatoxin and an increase in lead concentration (inactive level $-0,04 \mathrm{mg} / \mathrm{dm} 3 ; \mathrm{R} 2=0,09 ; \mathrm{p} \leq 0,0001$ ) and $\mathrm{O}$-cresol (inactive level $-0,0 \mathrm{mg} / \mathrm{dm} 3 ; \mathrm{R} 2=$ 0,$48 ; p \leq 0,0001$ ) in the blood (Figures 1 and 2).

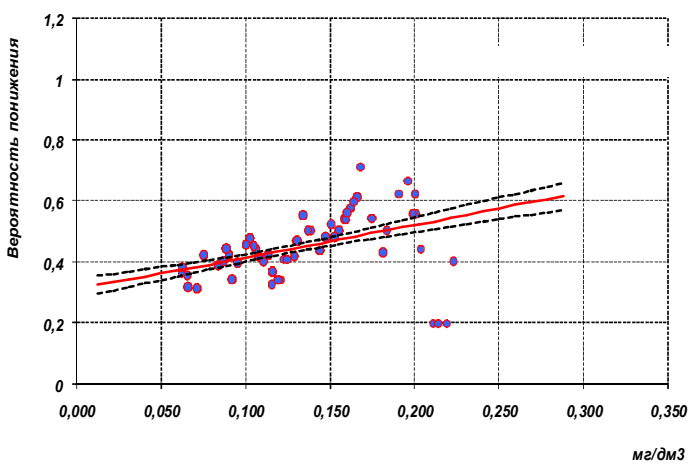

Figure 1. Correlation between a decrease in postvaccinal JgG level to diphtheria anatoxin and increase in lead concentration in the blood

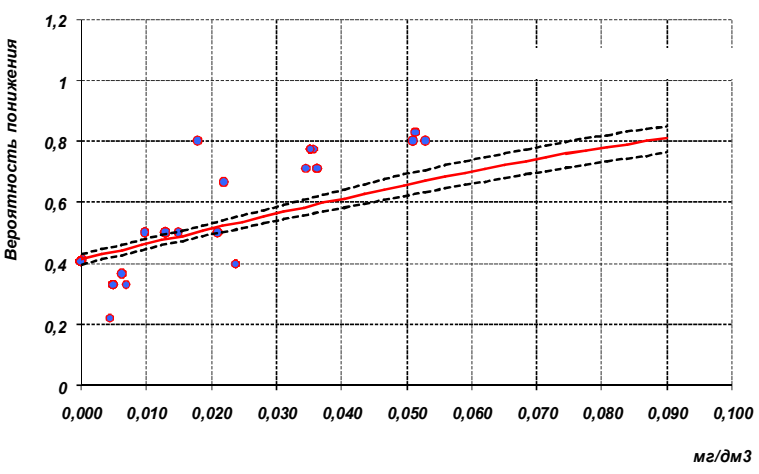

Figure 2. Correlation between a decrease in postvaccinal JgG level to diphtheria anatoxin and increase of O-cresol in the blood

Additionally, we determined an accurate decrease in the JgG level to pertussis agent with an increase in chrome level in the blood (inactive level 0,004 mg/dm3; R2 $=0,76 ; \mathrm{p} \leq 0,0001$ ) (Figure 3), and manganese level (inactive level - 0,011 mg/dm3; R2 $=0,80 ; \mathrm{p} \leq 0,0001$ ) (Figure 4).

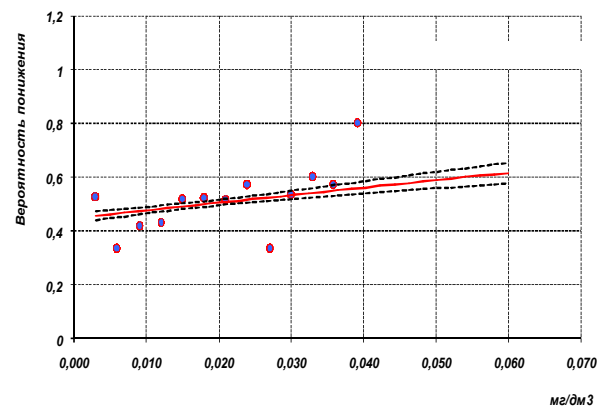

Figure 3. Correlation between a decrease in post-vaccinal JgG level to pertussis agen and an increase of chrome level in the blood

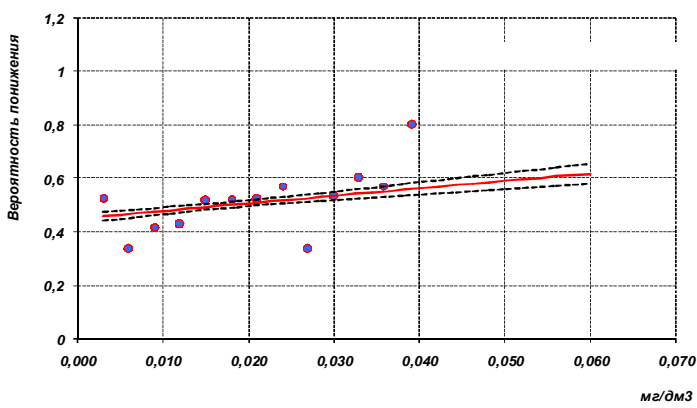

Figure 4. Correlation between a decrease in postvaccinal JgG level to pertussis agent and in increase of manganese concentration in the blood

Based on the above research, we can make the following conclusions:

1. Children with a higher level of chemical toxicants (manganese, lead, chrome, phenol, and o-cresol) in the blood caused by external environmental impact 3-5 years after the AKDS and JKV immunization / first re-immunization have a 1,3-10,4 times lower level of vaccineinduced antibodies as compared to the children living in the areas with favorable sanitary and hygienic environmental conditions.

2. Vaccine-induced dysimmunity (the level of vaccine-induced antibodies is below the protective level) in children with a higher level of manganese, chrome, lead, phenol, and o-cresol 
in the blood occurs 1.5-2.4 times more often as compared to the children with the chemical toxicants at the reference/background level

3. The absolute level of antibody-producing (CD19+) cells in children with higher level of technogenic chemical toxicants in the blood is accurately lower as compared to the children residing in the areas of favorable sanitary and hygienic environmental conditions.

4. We determined a true relationship between a decrease in the level of specific vaccineinduced antibodies and increase in the level of lead, chrome, manganese, and o-cresol.

\section{References}

1. Briko N.I. Politika i mehanizmy prinjatija reshenij v oblasti immunoprofilaktiki v RF: doklad na III Ezhegodnom Vseros. kongresse po infekcionnym boleznjam [The policy and the mechanisms of decision-making in the field of immunoprophylaxis in the Russian Federation]. Moscow, 2011. Available at: http://www.congress-infection.ru/archiv.htm.

2. Vasneva Zh.P., Beljaeva L.V., Shaposhnikova S.V. Naprjazhennost' postvakcinal'nogo gumoral'nogo immuniteta $\mathrm{u}$ detej [Post-vaccination humoral immunity stress in children]. Organizacionnye, diagnosticheskie $i$ lechebnye aspekty dejatel'nosti uchrezhdenij zdravoohranenija: sbornik nauchnyh trudov, Voronezh, 200, pp. 187-190.

3. Zverev V.V., Juminova N.V. Jeffektivnost' vakcinacii protiv kori i jepidemicheskogo parotita [The effectiveness of vaccination against measles and mumps]. Vakcinacija. Novosti vakcinoprofilaktiki, 2000, Vol. 11, no. 5, pp. 10-11.

4. Zaitseva N.V., Ulanova T.S., Plahova L.V., Suetina G.N. Vlijanie polimetallicheskih zagrjaznenij ob\#ektov okruzhajushhej sredy na izmenenie mikrojelementnogo sostava biosred u detej [The impact of polymetallic pollution of the environment on changes in the content of trace elements in biological media in children]. Gigiena i sanitarija, 2004, no. 4, pp. 11.

5. Zaitseva N.V., Zemlyanova M.A., Kiriyanov D.A. Ocenka adaptacionnoprisposobitel'nyh reakcij $\mathrm{u}$ detej $\mathrm{v}$ uslovijah hronicheskogo vozdejstvija himicheskih faktorov [An assessment of adaptive responses in children chronically exposed to chemical factors]. Jekologija cheloveka, 2005, no. 9, pp. 29-31.

6. Zaitseva N.V., Ulanova T.S., Dolgih O.V., Karnazhickaja T.V. Obosnovanie maksimal'no nedejstvujushhej koncentracii formal'degida $\mathrm{v}$ krovi detej, prozhivajushhih na territorijah s razlichnoj antropogennoj nagruzkoj [The justification of the no observed effect concentration of formaldehyde in children's blood in areas with different levels of anthropogenic pollution]. Permskij medicinskij zhurnal, 2010, Vol. 27, no. 1, pp. 101-104.

7. Zaitseva N.V., Ustinova O.Ju., Aminova A.I. Gigienicheskie aspekty narushenija zdorov'ja detej pri vozdejstvii himicheskih faktorov sredy obitanija: rukovodstvo [Hygienic aspects of health disorders in children exposed to chemical environmental factors: guidelines. Ed. N.V. Zajceva. Perm': Knizhnyj format, 2011. 489 p.

8. Ilyina S.V. Vliyanie tehnogennogo zagrjaznenija okruzhajushhej sredy na jeffektivnost' vakcinoprofilaktiki u detskogo naselenija: avtoref. diss. ... doktora medicinskih nauk [The influence of anthropogenic pollution on the effectiveness of preventive vaccination in children: summary of the thesis ... of Dr. of Med. Sciences]. Irkutsk, 2008. 24 p.

9. Ilyina S.V., Dronova M.A. i dr. Kokljush na territorijah s vysokim urovnem tehnogennogo zagrjaznenija okruzhajushhej sredy [Pertussis in areas with high levels of technogenic environmental pollution]. Jepidemiologija i infekcionnye bolezni, 2007, no. 1, pp. $18-21$.

10. Ilyina S.V., Stepanenko L.A. i dr. Vakcinoprofilaktika poliomielita zhivoj poliovakcinoj $\mathrm{v}$ uslovijah jekologicheskogo neblagopoluchija [Preventive vaccination against 
poliomyelitis using a live polio vaccine in environmentally unfavorable areas]. Sibirskij medicinskij zhurnal, 2005, Vol. 56, no. 7, pp. 48-50.

11. Savilov E.D., Kolesnikov S.I., Krasovskij G.N. Infekcija i tehnogennoe zagrjaznenie: Podhody k upravleniju jepidemiologicheskim processom [Infection and technogenic pollution: approaches to the management of the epidemiological process]. Novosibirsk: Nauka, 1996. 188 p.

12. Karal'nik B.V., Markova S.G. Jekologicheskie aspekty AKDS-vakcinacii [Environmental aspects of DPT vaccination]. Zhurnal mikrobiologii, jepidemiologii $i$ immunobiologii, 1991, no. 12, pp. 34-38.

13. Onishhenko G.G., Ezhlova E.B. i dr. O realizacii meroprijatij tret'ego jetapa Programmy likvidacii kori v Rossijskoj Federacii [On the implementation of the third stage of The Measles Elimination Program in the Russian Federation]. Jepidemiologija i infekcionnye bolezni, 2011, no. 3, pp. 4-10.

14. Oskirko A.A. Nespecificheskaja mediko-jekologicheskaja reabilitacija kak put' povyshenija specificheskogo immuniteta protiv difterii $\mathrm{V}$ periody mezhdu planovymi revakcinacijami [Non-specific health and environmental rehabilitation as a way to increase specific immunity against diphtheria over the periods of time between routine revaccination]. Pediatrija, 1997, no. 2, pp. 110-111.

15. Popova A.Ju. Vlijanie zagrjaznenija okruzhajushhej sredy hlorirovannymi bifenilami na nespecificheskuju rezistentnost' i postvakcinal'nyj immunitet: avtoref. diss. ... kand. med. nauk [The impact of environmental pollution with chlorinated biphenyls on non-specific resistance and post-vaccination immunity: summary of the thesis ... of $\mathrm{PhD}$ in Medicine]. Moscow, 1997. 23 p.

16. Rahmanin Ju.A., Revazova Ju.A. Donozologicheskaja diagnostika v probleme «okruzhajushhaja sreda - zdorov'e naselenija» [Pre-nosological diagnosis in the «environment human health» problem]. Gigiena i sanitarija, 2004, no. 6, pp. 3-5.

17. Semenov B.F., Zverev V.V., Haitov R.M. Ozhidaemye sobytija v razvitii vakcinoprofilaktiki do 2020-2030 gg. [Upcoming events in the development of preventive vaccination up to the years 2020-2030]. Zhurnal mikrobiologii, jepidemiologii i immunobiologii, 2010, no. 2, pp. 105-111.

18. Skachkov M.V., Vereshhagin N.N. Osobennosti jepidemicheskogo processa na territorijah s razlichnym urovnem antropogennoj nagruzki [The features of the epidemic process in areas with different levels of anthropogenic pollution]. Jepidemiologija $i$ vakcinoprofilaktika, 2004, no. 3, pp. 14-18.

19. Selezneva T.S. Vlijanie vakcinoprofilaktiki na jepidemicheskij process upravljaemyh infekcij v Rossijskoj Federacii [The impact of preventive vaccination on the epidemic process of vaccine preventable infections in the Russian Federation]. Jepidemiologija i infekcionnye bolezni, 2002, no. 2, pp. 6-11.

20. Feldbljum I.V. Vakcinoprofilaktika kak zhiznesberegajushhaja tehnologija i instrument demograficheskoj politiki [Preventive vaccination as a life-saving technology and a tool of population policy]. Jepidemiologija i infekcionnye bolezni. Aktual'nye voprosy, 2011, no. 2, pp. 14-16. 


\section{A b o ut the a uthors:}

Aminova Alphiya Irshadovna (Perm, Russia) - Doctor of Medical Sciences, leading research officer at the Federal Scientific Center for Medical and Preventive Health Risk Management Technologies" (82 Monastyrskaya St, Perm, 614045, e-mail: aminova@fcrisk.ru; tel: +7-(342)- 237-30-70).

Professor Ustinova Olga Yurievna, DSc in Medicine (Perm, Russia) - Deputy Director for Healthcare Services, the Federal Budget Scientific Institution "Federal Scientific Center for Medical and Preventive Health Risk Management Technologies" (82 Monastyrskaya St, Perm, 614045, email: ustinova@fcrisk.ru; tel.:+7-(342)-236-32-64).

Makarova Venera Galimzyanovna (Perm, Russia) - Allergist-Immunologist, the Federal Budget Scientific Institution "Federal Scientific Center for Medical and Preventive Health Risk Management Technologies" (82 Monastyrskaya St, Perm, 614045, email: root@fcrisk.ru; tel.: +7-(342)-236-32-64).

Professor Dolgikh Oleg Vladimirovich, DSc in Medicine (Perm, Russia) - Head of the Department of Immunobiological Diagnostics, the Federal Budget Scientific Institution "Federal Scientific Center for Medical and Preventive Health Risk Management Technologies" (82 Monastyrskaya St, Perm, 614045, email: oleg@fcrisk.ru; tel.: +7-(342)- 236-39-30). 